\title{
Polymorphism in the PPARgamma2 and beta2-adrenergic genes and diet lipid effects on body composition, energy expenditure and eating behavior of obese women is
}

\author{
Eliane Lopes Rosado ${ }^{\mathrm{a}, *}$, Josefina Bressan ${ }^{\mathrm{b}}$, Marta F. Martins ${ }^{\mathrm{c}}$, Paulo R. Cecon ${ }^{\mathrm{d}}$, \\ Jose Alfredo Martínez \\ ${ }^{a}$ Departamento de Nutrição e Dietética, Instituto de Nutrição, Universidade Federal do Rio de Janeiro, Avenida Brigadeiro Trompowski S/N, \\ Edifício do CCS, Bloco J, $2^{\circ}$ andar, Cidade Universitária, Ilha do Fundão, Rio de Janeiro RJ 21941-590, Brazil \\ ${ }^{\mathrm{b}}$ Departamento de Nutrição, Universidade Federal de Viçosa, Campus Universitário S/N, Viçosa MG 36570-000, Brazil \\ ${ }^{\mathrm{c} I n s t i t u t o ~ d e ~ B i o t e c n o l o g i a ~ A p l i c a d a ~ a ̀ ~ A g r o p e c u a ́ r i a-B i o a g r o, ~ U n i v e r s i d a d e ~ F e d e r a l ~ d e ~ V i c ̧ o s a, ~ C a m p u s ~ U n i v e r s i t a ́ r i o ~ S / N, ~ V i c ̧ o s a ~ M G ~ 36570-000, ~ B r a z i l ~}$ \\ ${ }^{\mathrm{d}}$ Departamento de Informática, Universidade Federal de Viçosa, Campus Universitário S/N, Viçosa MG 36570-000, Brazil
}

Received 21 January 2006; received in revised form 10 April 2007; accepted 12 April 2007

\begin{abstract}
In order to evaluate the effect of polymorphism in the PPARgamma2 and beta2-adrenergic genes and diet lipids on body composition, energy expenditure and eating behavior of obese women, 60 subjects were submitted to anthropometric, biochemical, dietary, molecular, basal and postprandial metabolism (indirect calorimetry) and eating behavior (visual analog scale) evaluation. Fat and saturated fatty acid (SFA) high diet was used to assess postprandial metabolism. The frequency of Pro12Pro/Gln27Gln, Pro12Pro/Gln27Glu, Pro12Pro/ Glu27Glu and Pro12Ala/Gln27Glu genotypes was 35.71\%, 30.37\%, 23.21\% and 10.71\%, respectively. These values were not significant $(p>0.05)$ for the dietary, anthropometric, biochemical and metabolic parameters. The Pro12Ala/Gln27Glu group was found to present greater energy used in postprandial period (EUPP). The presence of the PPARgamma2 gene variant, independent of beta2-adrenergic gene polymorphism, resulted in fat oxidation increase. Also, this group presented higher satiety, compared to the Pro12Pro/Gln27Gln group. The presence of the variant alleles in the PPARgamma2 gene suggests benefits in food intake control.
\end{abstract}

(C) 2007 Elsevier Ltd. All rights reserved.

Keywords: Obesity; PPARgamma2; Beta2-adrenergic receptor; Diet; Energy metabolism; Eating behavior

\section{Introduction}

The prevalence of overweight and obese people is increasing worldwide in both developed and developing countries (Document of Latin American Consensus on Obesity, 1999). In Brazil, overweight rates for the population over 20 is $40.6 \%$, with obesity rates of $8.8 \%$ for men and $12.7 \%$ for women (POF, 2004). In Spain, $11.9 \%$ men and $13.6 \%$ women are obese (Martínez, Moreno, \& Martínez-Gonzales, 2004).

\footnotetext{
This research was carried out at Departamento de Fisiología y Nutrición, Facultad de Farmacia, Universidade de Navarra, Edifico de Ciencias, Calle Irunlarrea S/N, Pamplona, Navarra 31008, España.

${ }^{*}$ Corresponding author.

E-mail address: elianerosado@nutricao.ufrj.br (E.L. Rosado).
}

Low-energy expenditure and increase in food intake are involved in obesity, with the most important factors being difficult to determine (Bray, 1976; Monteiro \& Halpern, 2000; Wolff, 1997).

The risk of developing obesity has a genetic component and many studies have quantified loci and candidate genes involved in its etiology. Human genome sequencing has offered numerous benefits to the study of genetic polymorphism, helping identify possible risks caused by the alleles, in addition to the development of genomic technologies that favor the study of diagnosis and treatment of obesity (Kowalski, 2004).

According to Perusse et al. (2001), this number is increasing, with a total of 54 new loci being added to the genetic map of human obesity last year, and the number of 
marked genes and chromosomal regions that have been associated with human obesity being presently around 250 . Additionally, an increase in DNA sequence alterations in genes specific to the obesity phenotype has become evident, with 130 studies reporting positive association with 48 candidate genes. The genetic map of obesity reveals that the loci affecting obesity-related phenotypes may be found in all chromosomes, except Y.

Efforts to identify candidate genes for obesity have concentrated on adipose tissue, since thermogenesis regulation through the symphatic nervous system carried out by the brown adipose tissue is mediated by the betaadrenergic receptors. Also, the PPARgamma (peroxisome proliferators-activated receptor gamma) plays an important role in adipogenesis and may control 30 genes responsible for the environmental signs linked to nutrients, such as fatty acids (Froguel \& Boutin, 2001).

The PPARgamma2 gene is expressed preferably in differentiated adipocytes (Medina, Sewter, \& Vidal-Puig, 2000) and mediates the expression of specific fat tissue cell genes (Spiegelman, Castillo, Hauser, \& Puigservar, 1999) that codify proteins directly related to the lipogenic pathways (Desvergne \& Wahli, 1999). Hence, this gene affects the fatty acid stock in fat tissue, participating in adipocyte differentiation by inducing pre-adipocyte maturation in fat cells. It acts by stimulating hydrolysis of the circulating triglycerides (TG) and subsequent entry of the fatty acids in the adipose cells. It also stimulates binding and activation of cytosol fatty acids, events required for TG synthesis (Gregoire, Smas, \& Sul, 1998; Kersten, Desvergne, \& Wahli, 2000) and participates also in adipocyte hypertrophy (Kubota et al., 1999).

Fat tissue accumulation occurs by means of three mechanisms: proliferation of pre-adipocytes found in fat deposits, its differentiation in adipocytes capable of storing fat, and through imbalance between lipogenesis and lipolysis, favoring the former. All these events are dependent on environmental and genetic factors. Adipogenesis persists throughout life and may be influenced by diet size, frequency and composition. Certain adipogenic transcription factors, such as PPARgamma, which interacts with cell-cycle regulating proteins, once modified, result in changes in gene expression related to adipogenesis (Palou, Bonet, \& Rodríguez, 2001).

Malczewska-Malec et al. (2004) evaluated the relation among risk factors associated with obesity, including insulin-resistance, lipid tolerance, arterial hypertension, endothelial function and genetic polymorphisms; with appetite regulation, adipocyte differentiation and insulinsensitivity, thermogenesis and fatty acid catabolism. The relation between obesity and certain genetic polymorphisms was observed.

Polymorphism of the PPARgamma2 gene is characterized by proline-to-alanine substitution at codon 12 (Deeb et al., 1998).

Studies on obese men and women show conflicting results when considering the relation between the variant in
PPARgamma2 gene and obesity (Bearmer et al., 1998; Valve et al., 1999). Deeb et al. (1998) suggest that polymorphism of the PPARgamma2 gene has been associated with reduction of body mass index (BMI) (Deeb et al., 1998) and alteration of gene function. Kubota et al. (1999) evaluated mice with one function allele in the PPARgamma gene (Pro12Ala), and verified resistance to obesity development. However, Valve et al. (1999) observed that obese women with the Ala12Ala genotype had increased BMI, lean body mass, fat mass, and waist and hip circumferences compared with the women with the Pro12Pro or Pro12Ala genotypes.

There are various ligands of this gene (Houseknecht, Cole, \& Steele, 2002; Mori et al., 1998), including polyunsaturated fatty acids (PUFA) (Azcárate, Moral, \& Hernández, 2000; Houseknecht et al., 2002). Thus, change in the PUFA content in the dietary content could increase lipogenesis in subjects without the variant allele in the PPARgamma2 gene.

Dietary fatty acids influence various metabolic routes in an array of organs. Part of this influence causes alteration in mRNA activation. Under intense energetic restriction or fasting, activation of TG removal from the fat tissue occurs and large amounts of fatty acids are released into the liver, with the events occurring in this organ being influenced by PPAR (Kersten et al., 2000). On the other hand, high-fat diets promote adipocyte differentiation (Margareto, Larrarte, Marti, \& Martínez, 2001; Vidal-Puig et al., 1996). Low fatty acid levels in animals fed high fat diets may occur because such diets could induce fat accumulation, using the circulating fatty acids (Berraondo, Marti, Duncan, \& Martínez, 2000). With a high-fat diet adipocyte increased hypertrophy and insulin resistance are produced, while in rodents with polymorphism of the PPARgamma gene, the same effect has not been observed (Kubota et al., 1999).

In contrast, the beta2-adrenergic receptors are mediators of the lipolytic effects of the catecholamines (Meirhaeghe et al., 2001), participating in energetic homeostasis, since they stimulate the reduction of glycogen use and the increase of lipid mobilization (Arner, 2001). The beta2adrenergic receptors ( $\beta 2-\mathrm{AR})$ gene was found to be expressed in subcutaneous fat tissue (Large et al., 1997). However, abdominal fat has a higher density and sensitivity to the beta-adrenergic receptor gene, and in obese individuals with increase waist circumference (WC), beta2-adrenergic gene activity is higher (Meirhaeghe et al., 2001). The presence of the variant in this gene, characterized by a glutamine-to-glutamic acid substitution at codon 27, is associated with body weight gain (Hellström, Large, Reynisdottir, Wahrenberg, \& Arner, 1999).

Thus, when considering the functions of the evaluated genes, it is suggested that polymorphism of the beta2adrenergic receptor gene promotes body weight gain in subjects on high fat diets, since it could reduce oxidation of the ingested fat. On the other hand, polymorphism of the PPARgamma2 gene would facilitate body weight loss in the presence of a high fat diet. 
In addition to the genetic factor, Ravussin and Bogardus (2000) suggest that, in different populations, obesity is greatly influenced by environmental factors, considering that subjects of the same community living in the same environment vary in body size and composition genetically determined as a response to the environment.

Eating behavior becomes an important factor when environmental factors are taken into account in obesity genesis.

Fats are known to have a lower satiation effect than carbohydrates, generating a passive over consumption of energy (Blundell, Burley, Cotton, \& Lawton, 1993).

Dietary fat and oil differ in fatty acid chain length, their degree of saturation, and the position and stoichiometric double-bound configuration, affecting their oxidation rates (Piers, Walker, Stoney, Soares, \& O'Dea, 2002), due to their relation with insulin resistance (Borkman et al., 1993). The oxidation speed of certain fatty acids is also related to satiety. Considering that saturated fatty acids (SFA) have slower oxidation speed than PUFA, the former favor fat deposition. Monounsaturated fatty acids (MUFA) favor lipid deposition as energy source in fat tissue, when compared with PUFA, thus exerting less control on appetite. It should be considered that oxidized lipids promote satiety whereas stored lipids do not (Friedman, 1998; Monteiro \& Mourão, 2002). Lawton, Delargy, Brockman, Smith, and Blundell (2000) reported also that PUFA offer better appetite control compared to PUFA and SFA.

In addition to lipids, carbohydrates have been associated with appetite control. They seem to be efficient in inhibiting appetite on a short-term basis, compared to fat, due to their oxidative priority, which reflects in satiety duration (Monteiro \& Mourão, 2002). Mourão, Monteiro, Hermsdorff, and Leite (2004) evaluated the effect of sucrose and its substitute (sucralose) on appetite and satiety in lean and overweight men, maintaining the fatty acid profile and the caloric density of the diets. It was verified that sucrose substitution and the increase of complex carbohydrates in the diet reduced hunger, and increased satiety, thermogenesis, resting respiratory quotient (RRQ), resting metabolic rate (RMR) and carbohydrate oxidation (CHOX), regardless of the group. However, overweight men showed higher energy expenditure and lower thermogenesis, when compared to lean men, regardless of diet.

Although evidence shows that obesity is a multifactor disease and that genes and the environment are related, few studies have associated the effect of one or more genes, and gene-environment interactions on energy expenditure and eating behavior. Hence, further and more detailed evaluations of these factors are required to clarify the differences in energy expenditure and eating behavior of obese subjects.

The purpose of this paper is to assess the effect of fat diet and polymorphism of the PPARgamma 2 and $\beta 2$-AR genes on energy expenditure and eating behavior of overweight women. Our aim is to acquire a deeper understanding of the possible interactions among the PPARgamma2 and beta2-adrenergic genes, dietary and metabolic factors in body weight variation.

\section{Methods}

\section{Subjects}

Fifty-six obese women (WHO, 1998) were selected, aged $20-49 \mathrm{yr}(34.6 \pm 7.6)$ and BMI between 30.00 and $56.46 \mathrm{~kg} \mathrm{~m}^{-2}(37.7 \pm 6.2)$. The women were submitted to nutritional evaluation to meet inclusion criteria, which considered women with $\mathrm{BMI} \geqslant 30 \mathrm{~kg} \mathrm{~m}^{-2}$, absence of diabetes, weight loss under $3 \mathrm{~kg}$ in the past 3 months, absence of menopause symptoms and chronic diseases.

\section{Experimental protocol}

The women were recruited in Pamplona (Spain). The study protocol (Fig. 1) was established and approved by the Department of Physiology and Nutrition of the School of Pharmacy of Navarra University.

Dietary evaluation was followed by a clinical assay, in which anthropometric, metabolic, biochemical and

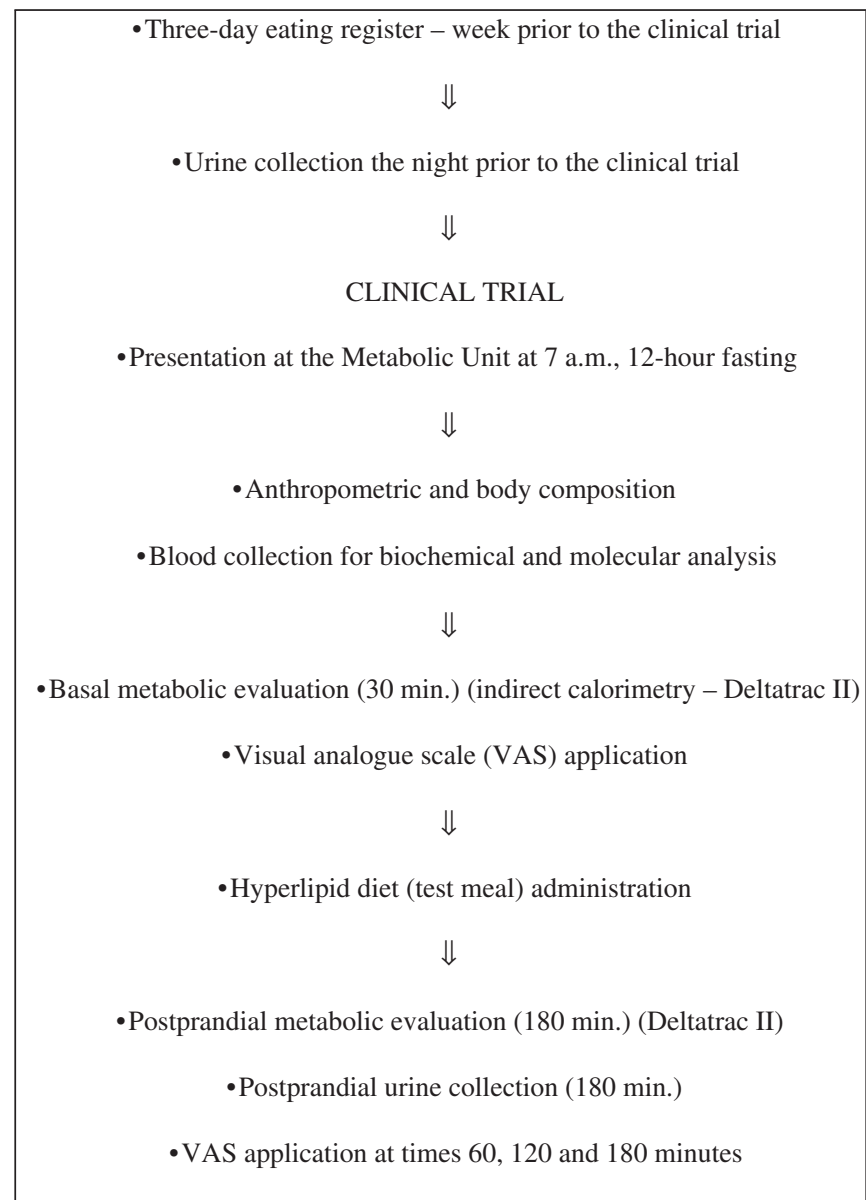

Fig. 1. Experimental protocol. 
molecular parameters and eating behavior were assessed. Groups were divided according to the genotypes of the evaluated genes.

During the trial, the women remained sedentary and were fed only the test meal and water.

\section{Assessment of habitual diet}

Usual diet intake was evaluated in the week prior to the clinical trial by means of a detailed food registry, 3 days per week, two typical and one atypical. Registry analysis was performed using the Medisystem (Sanocare SL) software.

\section{Anthropometric and body composition assessment}

The women were weighed using a micro digital electronic balance (Seca), with capacity of $150 \mathrm{~kg}$ and $100 \mathrm{~g}$ precision. Height was determined using a $0.5 \mathrm{~cm}$ scale vertical anthropometer (Geissler, Miller, \& Shah, 1987; Gibson, 1990). BMI was calculated (Bray \& Gray, 1988), and classified according to WHO (1998).

The bio-electrical impedance (BI) (Biodynamics model 310) method was used to evaluate total body water, and indirectly the fat-free mass (FFM) and total body fat (TBF) (Lukaski, Johnson, Bolonchuk, \& Lykken, 1985; Valtueña, Blanch, Barenys, Solá, \& Salas-Salvadó, 1995; Valve et al., 1999).

The relation between the WC and hip circumference was determined (Després, Lemieux, \& Prud'homme, 2001; Weinsier et al., 1995). The WC was also evaluated alone, due to its relation with co-morbidity risks (NCEP, 2001; WHO, 1998).

\section{Assessment of energy metabolism}

Energy metabolism was evaluated by indirect calorimetry using the Deltatrac II $^{\circledR}$ (Datex-Engstrom, Finland) monitor (Ferrannini, 1988). Oxygen $\left(\mathrm{O}_{2}\right)$ consumption and carbon dioxide $\left(\mathrm{CO}_{2}\right)$ production $(\mathrm{mL} / \mathrm{min})$ (Ferrannini, 1988; Valve et al., 1999); fasting ( $8 \mathrm{~h}$ ) and postprandial (3 h) urine nitrogen; and high-fat diet composition were used to calculate:

- Basal energy expenditure (BEE) (kcal/min)$\left.\left(16.4 \times \mathrm{VO}_{2}\right)+\left(4.5 \times \mathrm{VCO}_{2}\right)-\left(\mathrm{O}_{2}\right) 3.4 \times \mathrm{N}(\mathrm{g} / \mathrm{min})\right) / 4.18$ $(\mathrm{N}=$ urine nitrogen $)$.

- Non-protein respiratory quotient (NPRQ) and postprandial non-protein respiratory quotient $(\mathrm{PPNPRQ})=$ $\mathrm{NPVCO}_{2} \quad(\mathrm{~L} / \mathrm{min}) / \mathrm{NPVO}_{2} \quad(\mathrm{~L} / \mathrm{min}) . \quad \mathrm{NPVCO}_{2}=\mathrm{VCO}_{2}$ $(\mathrm{L} / \mathrm{min})-\mathrm{PVCO}_{2} \quad(\mathrm{~L} / \mathrm{min}) . \quad \mathrm{PVCO}_{2} \quad(\mathrm{~L} / \mathrm{min})=(\mathrm{N} \quad(\mathrm{g} /$ min $) \times 6.25 \times 0.774) . \quad \mathrm{NPVO}_{2}=\mathrm{VO}_{2} \quad(\mathrm{~L} / \mathrm{min})-\mathrm{PVO}_{2}$ $(\mathrm{L} / \mathrm{min}) . \mathrm{PVO}_{2}(\mathrm{~L} / \mathrm{min})=(\mathrm{N}(\mathrm{g} / \mathrm{min}) \times 6.25 \times 0.966)$.

- Basal lipid oxidation (BLOX) and postprandial lipid oxidation $(\mathrm{PPLOX})(\mathrm{g} / \mathrm{min})=\mathrm{NPVO}_{2} \times\left(1^{\mathrm{a}}-\mathrm{NPRQ}\right) /$ $\left(0.293^{\mathrm{b}} \times 2.019^{\mathrm{c}}\right)$. ${ }^{\mathrm{a}} \mathrm{Quotient}$ of complete oxidation of lipids, bdifference between 1 and $0.707,{ }^{\mathrm{c}} \mathrm{VO}_{2}(\mathrm{~L}) /$ oxidized lipids (g).
- Basal carbohydrate oxidation (BCHOX) (g/min)$\mathrm{NPVO}_{2} \times(\mathrm{NPRQ}-0.707) /\left(0.293 \times 0.829^{\mathrm{d}}\right) . \quad{ }^{\mathrm{d}} \mathrm{VO}_{2} \quad(\mathrm{~L}) /$ oxidized glucose (g).

- Postprandial carbohydrate oxidation (PPCHOX) $(\mathrm{g} / \mathrm{min})=\mathrm{NPVO}_{2} \times\left(\mathrm{NPRQ}-0.707^{\mathrm{e}}\right) /\left(0.293^{\mathrm{b}} \times 0.746^{\mathrm{f}}\right)$.

${ }^{\mathrm{e}}$ Quotient of the complete oxidation of carbohydrate, bdifference between 1 and $0.707,{ }^{\mathrm{f}} \mathrm{VO}_{2}$ (L)/oxidized glucose $(\mathrm{g})$.

- Thermic effect of food (TEF) $(\%)=\{[$ BMR $(\mathrm{kcal} / \mathrm{kg} /$ min) postprandial-BMR ( $\mathrm{kcal} / \mathrm{kg} / \mathrm{min})$ in fast] $\times$ $30 \times 100\} / \mathrm{kcal}$ of diet.

- Energy used in postprandial period $($ EUPP $)=(P P M R$ in $30 \mathrm{~min})+[($ PPMR in $60 \mathrm{~min} \times 30)+($ PPMR in $90 \mathrm{~min} \times 30)+\mathrm{PPMR}$ in $120 \mathrm{~min} \times 30)+(\mathrm{PPMR}$ in $180 \min \times 30)$ ].

Liquid protein oxidation was calculated to obtain nonprotein oxidation of other macronutrients (Ferrannini, 1988; Labayen, Forga, \& Martínez, 1999).

In order to evaluate postprandial energy metabolism a high-fat diet (95\%) and SFA (Fraîche cream) were used. The amount of the diet offered corresponded to $50 \%$ of the subject's total energy expenditure (TEE) (WHO, 1985).

Fasting urea and postprandial urine concentrations, used to calculate urinary nitrogen, were determined through the enzymatic method with urease and dehydrogenase glutamate.

\section{Assessment of eating behavior}

A visual analog scale (VAS) of $10 \mathrm{~cm}$ was used to evaluate eating behavior (appetite, satiety, satiation, urge to eat and thirst) (Alonso, Prieto, \& Antó, 1995). VAS was applied at times 0 (fasting), and 60,120 and $180 \mathrm{~min}$ after test diet intake. The questionnaire answers were not discussed or compared among the study volunteers.

\section{Biochemistry assessment}

Leptin, insulin, and TG levels were analyzed using blood samples collected during the clinical trial.

Serum levels of insulin (Boden, Chen, Kolacznski, \& Polansky, 1997) were determined by radioimmunoassay (RIA) technique (Valve et al., 1999) using the Coat-ACount ${ }^{\circledR}$ Insulin (Diagnostic Products Corporation) kit.

Serum levels of leptin were determined by immunoradiometric assay (IRMA) (Miles, Lipschitz, Bieber, \& Cook, 1974), using the Active ${ }^{\mathrm{TM}}$ Human Leptin IRMA (DSL-23100) (Diagnostic Systems Laboratories, Inc) kit.

Serum levels of TG were determined by means of a colorimetric enzymatic reaction using the GPO/PAP method (Valve et al., 1999) and measured photometrically (Cobas Mira).

\section{Molecular analysis}

Genomic DNA was isolated from the white cells in blood samples by organic extraction (phenol/chloroform) 
(Hellström et al., 1999), based on density gradient centrifugation. The samples were quantified in a spectrophotometer at 260,270, 280 and $310 \mathrm{~nm}$ and kept at $-20^{\circ} \mathrm{C}$ at $100 \mathrm{ng} / \mu \mathrm{L}$ concentration.

The detection of alleles Pro12Pro, Pro12Ala and Ala12Ala in the PPARgamma2 gene was carried out by means of DNA polymerase chain reaction (PCR) (Mullis \& Falooma, 1987), available in the GenBank DNA AB005520 (2003). The primers used were 5'-GCCAATTCAAGCCCAGTC- $3^{\prime}$ and 5'-GATATGTTTGCAGACAGTGTATC AGTGA AGGAATCGCTTTCC G-3'. The cycling conditions were curling temperature of $59^{\circ} \mathrm{C}$, denaturation temperature and time of $94^{\circ} \mathrm{C} / 5 \mathrm{~min}$, and extension temperature and time of $72{ }^{\circ} \mathrm{C} / 30 \mathrm{~s}$, totaling 35 cycles. The generated fragment was of $267 \mathrm{pb}$ (pairs of bases). After sample enzymatic digestion $\left(60^{\circ} \mathrm{C} / 180 \mathrm{~min}\right)$ using restriction enzyme Bst UI, the following fragments were generated: $267 \mathrm{pb}$ (Pro12Pro); 267, 224 and $43 \mathrm{pb}$ (Pro12Ala); and 224 and $43 \mathrm{pb}$ (Ala12Ala).

The detection of alleles Gln27Gln, Gln27Gluxc and Glu27Glu in the $\beta 2$-AR gene was carried out by means of PCR (Mullis \& Falooma, 1987), available in the GenBank DNA Y00106 (2003). The primers were 5'-CCGCCGTGGGTCCGCC- $3^{\prime}$ and 5'-CCATGACCAGATCAGCAGCAC-3'. The cycling conditions were curling temperature of $65^{\circ} \mathrm{C}$, denaturation temperature and time of $94{ }^{\circ} \mathrm{C} / 5 \mathrm{~min}$ and extension temperature and time of $72{ }^{\circ} \mathrm{C} / 30 \mathrm{~s}$, in a total of 35 cycles. The generated fragment was $310 \mathrm{pb}$. After enzymatic digestion of the samples $\left(37^{\circ} \mathrm{C} / 180 \mathrm{~min}\right)$ using restriction enzyme ITA I, the following fragments were generated: 171,84 and $55 \mathrm{pb}$ (Gln12Gln); 226, 171, 84 and $55 \mathrm{pb}$ (Gln12Glu); and 226, $84 \mathrm{pb}$ (Glu12Glu).

\section{Experimental design and data analysis}

The dietary, anthropometric, metabolic and biochemical parameters were analyzed using a completely randomized design with four treatments (A: Pro12Pro allele in PPARgamma2 gene and Gln27Gln in $\beta 2-A R$ gene; B: Pro12Pro in the PPARgamma2 gene and Gln27Glu in $\beta 2-A R$ gene, C: Pro12Pro allele in PPARgamma2 gene and Glu27Glu allele in $\beta 2$-AR gene, and D: Pro12Ala and Gln27Glu in PPARgamma2 and $\beta 2-\mathrm{AR}$ genes, respectively). The data were analyzed with ANOVA. Differences between the group means were evaluated by the Duncan test at $5 \%$ probability.

The data obtained from the VAS were analyzed using a split-plot scheme, with the groups constituting the plots (A, B, C and D) and the times constituting the split-plots $(0,60,120$ and $180 \mathrm{~min})$, in a completely randomized design. Data interpretation was performed using ANOVA, Duncan test at $5 \%$ probability, and regression analysis. The models were chosen based on regression coefficient significance, using the $t$-test at $1 \%$ probability, and on the coefficient of determination.

\section{Results}

\section{Frequency of genetic polymorphism}

Following molecular evaluation of the PPARgamma2 and $\beta 2$-AR genes, it was observed that $35.71 \%, 30.37 \%$, $23.21 \%$ and $10.71 \%$ of the women showed the genotypes Pro12Pro/Gln27Gln (group A), Pro12Pro/Gln27Glu (group B), Pro12Pro/Glu27Glu (group C) and Pro12Ala/ Gln27Glu (group D), respectively.

\section{Assessment of polymorphism effect on dietary, anthropometric, biochemical and metabolic parameters}

The phenotype of each genotype, characterized for the anthropometric and biochemical parameters did not differ among groups $(p>0.05)$ (Table 1).

No differences were observed among groups $(p>0.05)$ regarding energy and macronutrient intake and habitual diet lipid profile.

Considering the metabolic parameters, the EUPP was higher in group $\mathrm{D}$, compared to groups $\mathrm{A}, \mathrm{B}$ and $\mathrm{C}$ $(p<0.05)$, whereas the other parameters did not differ among groups $(p>0.05)$ (Table 2$)$.

Table 1

Anthropometric and biochemical characteristics of groups Pro12Pro/Gln27Gln (group A), Pro12Pro/Gln27Glu (group B), Pro12Pro/Glu27Glu (group C) and Pro12Ala/Gln27Glu (group D)

\begin{tabular}{|c|c|c|c|c|}
\hline Parameters/groups & Group A $(n=20)$ & Group B $(n=17)$ & Group C $(n=13)$ & Group D $(n=6)$ \\
\hline Age (years) & $33.5 \pm 6.6 \mathrm{a}$ & $34.4 \pm 8.3 \mathrm{a}$ & $35.5 \pm 7.9 \mathrm{a}$ & $36.7 \pm 9.0 \mathrm{a}$ \\
\hline BMI $\left(\mathrm{kg} \mathrm{m}^{-2}\right)$ & $38.0 \pm 7.0 \mathrm{a}$ & $35.9 \pm 3.5 \mathrm{a}$ & $38.3 \pm 6.5 \mathrm{a}$ & $40.4 \pm 9.0 \mathrm{a}$ \\
\hline Waist/hip ratio & $0.82 \pm 0.06 \mathrm{a}$ & $0.85 \pm 0.09 \mathrm{a}$ & $0.86 \pm 0.05 \mathrm{a}$ & $0.83 \pm 0.04 \mathrm{a}$ \\
\hline $\mathrm{WC}(\mathrm{cm})$ & $102.3 \pm 18.3 \mathrm{a}$ & $100.2 \pm 9.8 \mathrm{a}$ & $106.2 \pm 11.9 \mathrm{a}$ & $107.7 \pm 19.8 \mathrm{a}$ \\
\hline TFB $(\%)$ & $47.0 \pm 5.9 \mathrm{a}$ & $45.8 \pm 3.8 \mathrm{a}$ & $46.8 \pm 5.4 \mathrm{a}$ & $49.2 \pm 7.2 \mathrm{a}$ \\
\hline FFM $(\%)$ & $53.5 \pm 6.4 \mathrm{a}$ & $54.4 \pm 3.8 \mathrm{a}$ & $54.0 \pm 6.1 \mathrm{a}$ & $51.8 \pm 7.9 \mathrm{a}$ \\
\hline Leptin $\left(\mathrm{ng} \mathrm{mL} \mathrm{L}^{-1}\right)$ & $82.7 \pm 26.7 \mathrm{a}$ & $79.4 \pm 23.4 \mathrm{a}$ & $77.7 \pm 26.2 \mathrm{a}$ & $65.8 \pm 19.5 \mathrm{a}$ \\
\hline Insulin $\left(\mathrm{MIL} \mathrm{mL}^{-1}\right)$ & $11.1 \pm 7.5 \mathrm{a}$ & $13.0 \pm 10.0 \mathrm{a}$ & $12.3 \pm 5.9 \mathrm{a}$ & $11.6 \pm 9.6 \mathrm{a}$ \\
\hline Triglycerides $\left(\mathrm{mg} \mathrm{dL}^{-1}\right)$ & $97.8 \pm 44.4 \mathrm{a}$ & $84.8 \pm 35.9 \mathrm{a}$ & $93.1 \pm 34.8 \mathrm{a}$ & $77.7 \pm 22.7 \mathrm{a}$ \\
\hline
\end{tabular}

Means followed by the same letter in the line do not differ at $5 \%$ probability by the Duncan test.Abbreviations: BMI—body mass index; WC — waist circumference; TBF - total body fat; FFM — fat-free mass 
Table 2

Basal and postprandial metabolic characteristics of groups Pro12Pro/Gln27Gln (group A), Pro12Pro/Gln27Glu (group B), Pro12Pro/Glu27Glu (group C) and Pro12Ala/Gln27Glu (group D)

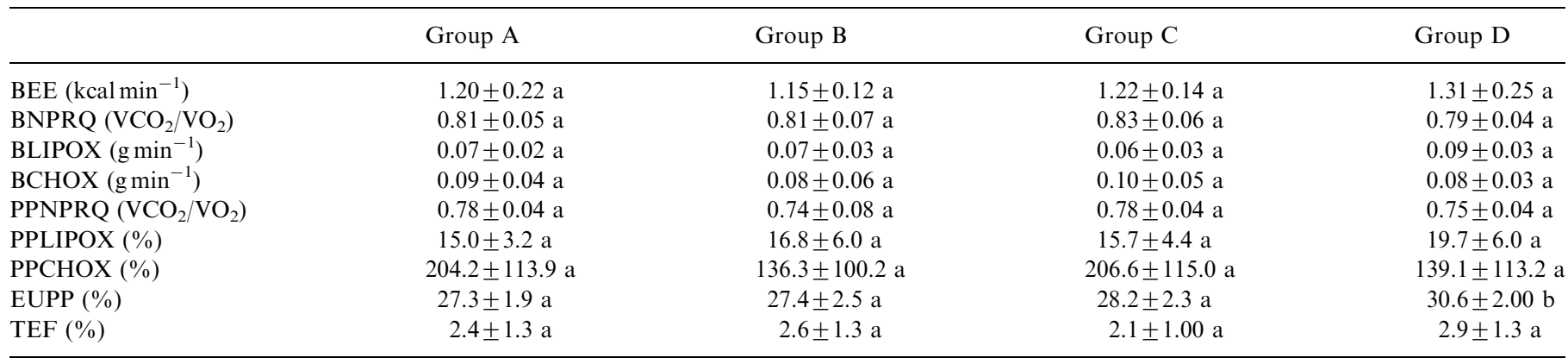

Means followed by the same letter in the line do not differ at $5 \%$ probability, Duncan test.

Abbreviations: BEE - basal energy expenditure; BNPRQ — basal non-protein respiratory quotient; BLIPOX — basal lipid oxidation; BCHOX — basal carbohydrate oxidation; PPNPRQ - postprandial non-protein respiratory quotient; PPLIPOX — postprandial lipid oxidation; PPCHOX - postprandial carbohydrate oxidation; EUPP — energy used in postprandial period; TEF — thermic effect of food.

Table 3

Mean values of hunger, satiety, satiation, urge to eat, and thirst sensations in Pro12Pro/Gln27Gln (group A), Pro12Pro/Gln27Glu (group B), Pro12Pro/ Glu27Glu (group C) e Pro12Ala/Gln27Glu (group D) women

\begin{tabular}{|c|c|c|c|c|c|}
\hline Groups & Hunger & Satiety & Satiation & Urge to eat & Thirsty \\
\hline $\mathrm{B}$ & $28.4 \pm 27.5 \mathrm{a}$ & $52.7 \pm 35.7 \mathrm{ab}$ & $58.4 \pm 32.5 \mathrm{a}$ & $36.4 \pm 32.5 \mathrm{a}$ & $60.6 \pm 32.0 \mathrm{a}$ \\
\hline $\mathrm{D}$ & $23.4 \pm 20.9 \mathrm{a}$ & $65.7 \pm 28.0 \mathrm{a}$ & $59.7 \pm 32.6 \mathrm{a}$ & $26.7 \pm 24.8 \mathrm{a}$ & $65.6 \pm 30.2 \mathrm{a}$ \\
\hline
\end{tabular}

Means followed by the same letter in the line do not differ at $5 \%$ probability, Duncan test.

\section{Assessment of eating behavior}

Table 3 shows that satiety did not differ among groups $\mathrm{B}, \mathrm{C}$ and $\mathrm{D}$. However, group $\mathrm{D}$ showed higher values $(p<0.05)$, compared to group A.

It was observed that high-fat diet resulted in a reduced feeling of hunger and urge to eat during the first $60 \mathrm{~min}$, and subsequent increase after $120 \mathrm{~min}$. The opposite was observed in the satiety and satiation curves, which increased the following intake and began reducing 120 min after intake. The feeling of thirst showed a linear increase from time 0 . No interaction was found between evaluation time and the groups (Fig. 2).

\section{Discussion}

The susceptibility to obesity is partly determined by genetic factors, but an "obesity-promoting environment" is typically necessary for its phenotypic expression.

The polymorphism frequency of PPARgamma2 and $\beta 2$ AR genes is not observed in other studies.

Mori et al. (1998) verified a low frequency of the polymorphism Pro12Ala in the gene PPARgamma2 (3\%) in Japanese men. Deeb et al. (1998) also observed frequency of $12 \%$ in the allele alanine in non-diabetic men and women. Ek et al. (1999) verified a frequency of $14 \%$ of the polymorphism Pro12Ala in obese men. van

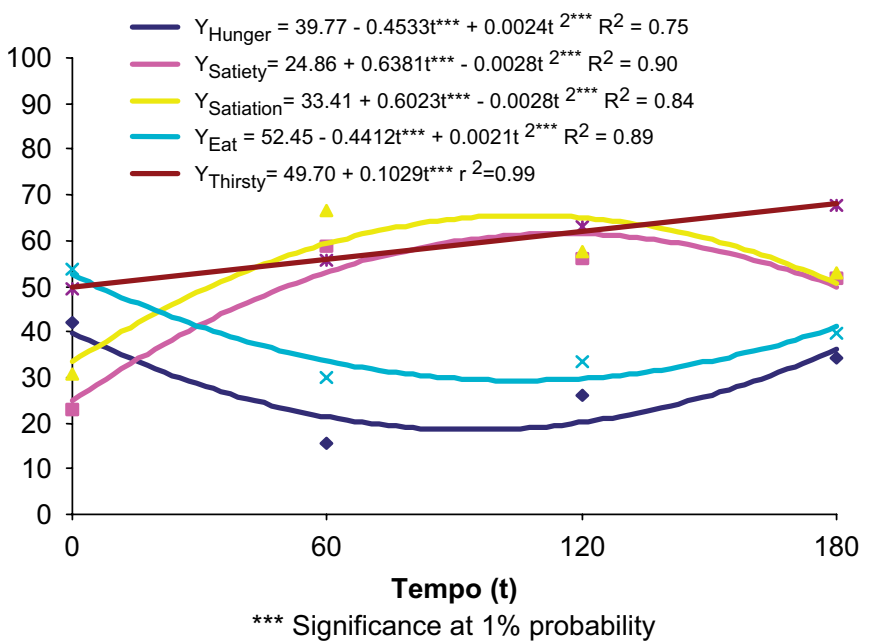

Fig. 2. Estimates of sensations of hunger, satiety, satiation, urge to eat and thirsty, in time (minutes), according to the Visual Analog Scale (VAS) in Pro12Pro/Gln27Gln (group A), Pro12Pro/Gln27Glu (group B), Pro12Pro/Glu27Glu (group C) and Pro12Ala/Gln27Glu (group D) women. $(* * *)$ Significance at $1 \%$ probability.

Rossum et al. (2002) verified that $75.4 \%, 23.1 \%$ and $1.5 \%$ of the obese men and $79.7 \%, 20.3 \%$ and $0 \%$ of the nonobese men presented the genotypes Pro12Pro, Pro12Ala and Ala12Ala, respectively. Also, $76.7 \%, 22.6 \%$ and $0.7 \%$ 
of the obese women and $73.7 \%, 25.7 \%$ and $0.6 \%$ of the non-obese women presented the genotypes Pro12Pro, Pro12Ala and Ala12Ala, respectively. No difference was observed among the groups.

Meirhaeghe, Helbecque, Cottel, and Amouyel (1999) verified that the frequency of the genotypes Gln27Gln, Gln27Glu and Glu27Glu was $33.1 \%, 51.0 \%$ and $15.9 \%$, respectively. van Rossum et al. (2002) verified that $30.7 \%$, $53.0 \%$ and $16.3 \%$ of the obese men; $26.7 \%, 55.8 \%$ and $17.5 \%$ of the non-obese men; $34.4 \%, 45.7 \%$ and $19.9 \%$ of the obese women; and $31.5 \%, 49.1 \%$ and $19.4 \%$ of the non-obese women presented the genotypes Gln27Gln, Gln27Glu and Glu27Glu, respectively. No differences were observed among the groups.

According to Bearmer et al. (1998) and Valve et al. (1999), studies on obese men and women show conflicting results when considering the relation between the variant in PPARgamma2 gene and obesity, since some verified a significant increase of BMI and WC in subjects with Pro12Ala polymorphism, whereas others reported that the variant is associated with the lowest BMI.

Deeb et al. (1998) evaluated lean adult men and women and verified that the presence of the variant in the PPARgamma2 gene was related to reduced fasting insulin concentration.

When evaluating lean subjects, Luan et al. (2001) verified that the presence of the allele alanine in the PPARgamma2 gene led to adiposity reduction following intake of PUFArich diets, and considering that some fatty acid derivatives are ligands of PPAR, they are expected to more effectively stimulate adipogenesis in Pro12Pro than in Pro12Ala. The authors confirmed the relation between the type of fatty acid and Pro12Ala polymorphism in fasting insulin, since increase in the diet's PUFA:SFA ratio caused BMI and insulin reduction, whereas PUFA:SFA ratio reduction resulted in higher BMI, compared to Pro12Pro subjects. This finding could reflect also an increase in hormone resistance.

In the present study, intake of a high-fat and SFA diet promoted higher lipid oxidation, in the short term, in women with the alanine variant, due to EUPP increase in group D.

In view of the lack of data showing a possible interaction between the two evaluated genes, it is important to propose a study on the effect of fatty acid type on different allele combinations of the different obesity candidate genes, as well as an increase in the sample size.

It is known that genetic factors also affect the parameters related to eating behavior such as appetite and satiety, which influence obesity pathogenesis.

The presence of the alanine allele in the PPARgamma2 gene led to satiety increase, since groups $\mathrm{B}$ and $\mathrm{C}$, which had variant alleles in the $\beta 2$-AR gene, did not differ in relation to it. There seems to be no difference in gene expression between the alleles of the PPARgamma2 and $\beta 2-\mathrm{AR}$ genes. This result suggests that satiety is determined by an association of the two genes.
A smaller insulin concentration in women with the variant alanine in the PPARgamma2 gene could result in anabolism reduction and consequent increase in plasma nutrient concentration, what explains higher satiety in women with the allele alanine.

As previously discussed, Lawton et al. (2000), Monteiro and Mourão (2002), and Friedman (1998) reported the existence of variation in the oxidation velocity of certain fatty acids, which influences satiety. PUFA would favor satiety, compared with MUFA and SFA. However, no data are available on evaluation of appetite variation and satiety in obese subjects with polymorphism of PPARgamma 2 and $\beta 2$-AR genes. Considering that group D showed a higher EUPP and that the ingested diet was high fat and SFA, it is suggested that there is a tendency for higher lipid oxidation in this group. Thus, increased lipid oxidation would favor satiety.

Houseknecht et al. (2002) reported the function of PPARgamma in various physiological and physiopathological events, including stimulating insulin action and lipid metabolism regulation. Activation of the gene improves insulin action, which is reduced during adipocyte differentiation. In humans, the presence of the alanine allele is related to reduction of fasting insulin concentration; however, these subjects may show less amount of fat tissue, leading to insulin sensitivity (Deeb et al., 1998).

The adrenergic receptor genes regulate lipid mobilization, energy expenditure and glycogen depression (Barber, Millet, Galitzki, Lafontan, \& Berlan, 1996). The $\beta 2$-AR family mediates the lipolytic effects of catecholamines (Meirhaeghe et al., 2001), which stimulate lipid mobilization, having an opposite effect of insulin (Flatt, 1996). Hellström et al. (1999) believe that polymorphism in the $\beta 2$-AR gene could lead to obesity.

Hence, the glutamic acid variant in codon 27 of the $\beta 2$ AR gene would cause the lipolytic effects of catecholamines, possibly leading to a potential insulin effect and appetite increase.

Valet et al. (2000) demonstrated how the two genes for alpha 2 and beta 3 -adrenergic receptors and diet interact to influence fat mass.

van Rossum et al. (2002) investigated the association between DNA polymorphism in several candidate genes for obesity and weight gain. Polymorphisms in these genes may contribute to weight gain through effects on energy intake, energy expenditure or adipogenesis. This study compared 286 subjects aged 20-40 years who gained an average of $12.8 \mathrm{~kg}$ during a mean follow-up of 6.8 years with 296 subjects who remained relatively constant over the same period with respect to occurrence of several polymorphisms in candidate genes of obesity and some lifestyle factors. Only variations in the $\beta 2-\mathrm{AR}$ gene (Gly16Arg and Gln27Glu) and leptin genes appeared to susceptibility to weight gain. The study suggests further research was necessary to establish the role of lifestyle factors, or interactions between genes or between genes and lifestyle factors on weight gain with age. 
The eating behavior of obese subjects may be explained by some mechanisms. According to group D results, one should consider the fact that obese subjects with a high percentage of TBF, almost always insulin-resistant, have a high yield and secretion of the tumoral necrosis factor $(\mathrm{TNF} \alpha)$. TNF $\alpha$ reduces the expression of the lypogenic genes, including PPARgamma2, which already shows altered functions in the presence of the allele alanine. In addition, it reduces appetite and promotes leptin secretion by adipocytes, which has been related to energy homeostasis, in comparison to insulin. The variant allele in the $\beta 2$-AR gene would also lead to increased insulin production but resistance to hormone action and the more pronounced function of the circulating leptin would reduce the effect of insulin. On the other hand, a high fat diet may reduce insulin levels and increase food intake. However, fatty acid type influences nutrient metabolism. Other results obtained by the researchers showed that women in group D with higher BMI and higher intake of habitual SFA had also higher fasting insulin levels.

Kubota et al. (1999) evaluated mice with one function allele in the PPARgamma gene (Pro12Ala), and verified resistance to obesity development, in part due to hyperleptinemia and subsequent hypophagia. It was also verified that a high-fat diet produces increased insulin resistance in subjects with the Pro12Pro allele in the PPARgamma2 gene. In view of this, differences in eating behavior were found to depend on the subject's genotype.

Further studies are needed to elucidate the effect of the interaction of different genes related to obesity with environmental factors such as diet, anthropometric, biochemical and metabolic parameters, and eating behavior. This knowledge will be of great importance in the dietary planning for obese subjects with different genetic characteristics, helping them lose and maintain body weight.

\section{Acknowledgment}

The authors would like to acknowledge the contributions of CAPES (Coordenação de Aperfeiçoamento de Pessoal de Nível Superior).

\section{References}

Alonso, J., Prieto, L., \& Antó, J. M. (1995). La versión española del SF-36 health survey (Cuestionario de Salud SF-36): Un instrumento para la medida de los resultados clínicos. Medicina Clínica, 104, 771-776.

Arner, P. (2001). Genetic variance and lipolysis regulation: Implications for obesity. Annals de Medicina, 33(8), 542-546.

Azcárate, T. M., Moral, A. M., \& Hernández, A. M. (2000). Estudios genéticos de la obesidad en humanos. Medicina Clínica, 115, 103-110.

Barber, P., Millet, L., Galitzki, J., Lafontan, M., \& Berlan, M. (1996). In situ assessment of the role of beta 1-, beta 2-, and beta 3 -adrenoreceptors in the control of lipolysis and nutritive blood flow in human subcutaneous adipose tissue. British Journal of Pharmacology, 117, 907-913.

Bearmer, B., Yen, C. J., Andersen, R., Muller, D., Elaki, D., Cheskin, L. J., et al. (1998). Association of the Pro12Ala variant in the peroxisome proliferator activated receptor $\gamma 2$ gene with obesity in two Caucasian populations. Diabetes, 47, 1806-1808.

Berraondo, B., Marti, A., Duncan, J. S., \& Martínez, J. A. (2000). Up regulation of the muscle UCP gene expression by a new $\beta 3$ adrenoceptor agonist, trecadrine, in obese (cafeteria) rodents, but down regulation in lean animals. International Journal of Obesity, 24, 156-164.

Blundell, J. E., Burley, V. J., Cotton, J. R., \& Lawton, C. I. (1993). Dietary fat and the control of energy intake: Evaluating the effects of fat on meal size and post-meal satiety. American Journal of Clinical Nutrition, 57(suppl 5), 772-777.

Boden, G., Chen, X., Kolacznski, J. W., \& Polansky, M. (1997). Effects of prolonged hyperinsulinemia on serum leptin in normal. Journal of Clinical Investigation, 100(5), 1107-1113.

Borkman, N., Storlien, L. H., Pan, D. A., Jenkins, A. B., Chisholm, D. J., \& Campbell, L. V. (1993). The relation between insulin sensitivity and the fatty-acid composition of skeletal-muscle phospholipids. New England Journal of Medicine, 328(8), 238-244.

Bray, G. A. (1976). Drug therapy for the obese patient. In L. H. Smith (Ed.), The obese patient-Major problems in internal medicine (pp. 353-410). Philadelphia: W.B. Saunders.

Bray, G. A., \& Gray, D. S. (1988). Obesity I: Pathogenesis. Western Journal of Medicine, 149(4), 429-441.

Deeb, S. S., Fajas, L., Nemoto, M., Pipihlajamäki, J., Mykkänen, L., Kuusisto, J., et al. (1998). A Pro12Ala substitution in PPAR $\gamma 2$ associated with decrease receptor activity, lower body mass index and improved insulin sensitivity. Nature Genetics, 20, 284-287.

Després, J. P., Lemieux, I., \& Prud'homme, D. (2001). Treatment of obesity: Need to focus on high risk abdominally obese patients. $B M J$, 322, 716-720.

Desvergne, B., \& Wahli, W. (1999). Peroxisome proliferator-activated receptors: nuclear control of metabolism. Endocrine Reviews, 20(5), 649-688.

Documento do Consenso Latino-Americano sobre Obesidade (1999). Ministério da Saúde.

Ek, J., Urhammer, S. A., Sorensen, T. I. A., Andersen, T., Auwerx, J., \& Pdersen, O. (1999). Homozygosity of the Pro12Ala variant of the peroxisome proliferation-activated receptor- $\gamma 2$ (PPAR- $\gamma 2$ ): Divergent modulation effects on body mass index in obese and lean Caucasian men. Diabetologia, 42, 892-895.

Ferrannini, E. (1988). The theoretical bases of indirect calorimetry: A review. Metabolism, 37, 287-301

Flatt, J. P. (1996). Glicogen levels and obesity. International Journal of Obesity, 20(suppl 2), 1-11.

Friedman, M. I. (1998). Fuel partitioning and food intake. American Journal of Clinical Nutrition, 67(Suppl 3), 513-518.

Froguel, P., \& Boutin, P. (2001). Genetics of pathways regulating body weight in the development of obesity in humans. Experimental and Biological Medicine, 226(11), 991-996.

Geissler, C. A., Miller, D. S., \& Shah, M. (1987). The daily metabolic rate of the post-obese and the lean. American Journal of Clinical Nutrition, 45(5), 914-920.

GenBank DNA AB005520. Homo sapiens ppar.[gi:2605488]. Approached on 24/01/2003, from 〈http://www.ncbi.nlm.nih.gov/genbank $\rangle$.

GenBank DNA. Y00106. Human gene for be. [gi:29370]. Approached on 24/01/2003, from 〈http://www.ncbi.nlm.nih.gov/genbank $\rangle$.

Gibson, R. S. (1990). Principles of nutritional assessment. New York: Marcel Dekker (pp. 163-186).

Gregoire, F. M., Smas, C. M., \& Sul, A. H. S. (1998). Understanding adipocyte differentiation. Physiology Review, 78(3), 783-809.

Hellström, L., Large, V., Reynisdottir, S., Wahrenberg, H., \& Arner, P. (1999). The different effects of a Gln27Glu $\beta 2$-adrenoceptor gene polymorphism on obesity in males and in females. Journal of Internal Medicine, 245, 253-259.

Houseknecht, K. L., Cole, B. M., \& Steele, P. J. (2002). Peroxisome proliferator-activated receptor gamma $(\operatorname{PPAR} \gamma)$ and its ligands: A review. Domestic Animal Endocrinology, 22, 1-23. 
Kersten, S., Desvergne, B., \& Wahli, W. (2000). Roles of PPARs in health and diseases. Nature, 405(25), 421-424.

Kowalski, T. J. (2004). The future of genetic research on appetitive behavior. Appetite, 42(1), 11-14.

Kubota, N., Terauchi, Y., Miki, H., Tamemoto, H., Yamauchi, T., Komeda, K., et al. (1999). PPAR gamma mediates high-fat dietinduced adipocyte hypertrophy and insulin resistance. Molecular Cell, 4(4), 597-609.

Labayen, I., Forga, L., \& Martínez, J. A. (1999). Nutrient oxidation and metabolic rate as affected by meals containing different proportions of carbohydrate and fat, in healthy young women. European Journal of Nutrition, 38, 158-166.

Large, V., Hellström, L., Reynisdottir, S., Lönnqvist, F., Eriksson, P., Lannfelt, L., et al. (1997). Human beta-2 adrenoreceptor gene polymorphisms are highly in obesity and associated with altered adipocyte beta-2 adrenoreceptor functions. Journal of Clinical Investigation, 100, 3005-3013.

Lawton, C. L., Delargy, H. J., Brockman, J., Smith, F. C., \& Blundell, J. E. (2000). The degree of saturation of fatty acids influences postingestive satiety. Brasilian Journal Nutrition, 83(5), 473-482.

Luan, J., Browne, P. O., Harding, A. H., Halsall, D. J., O'rahilly, S., Chatterjee, K., et al. (2001). Evidence for gene-nutrient interaction at the PPAR $\gamma$ locus. Diabetes, 50, 686-689.

Lukaski, H. C., Johnson, P. E., Bolonchuk, W. W., \& Lykken, G. I. (1985). Assessment of fat-free mass using bioelectrical impedance measurement of the human body. American Journal of Clinical Nutrition, 41(4), 810-817.

Malczewska-Malec, M., Wybranska, I., Leszcynska-Golabek, I., Partyka, L., Hartwich, J., Jabrocka, A., et al. (2004). Analysis of candidate genes Polish families with obesity. (CHECAR) Clinical Chemistry and Laboratory Medicine, 42(5), 487-493.

Margareto, J., Larrarte, E., Marti, A., \& Martínez, A. (2001). Upregulation of a thermogenesis-related (UCP-1) and down-regulation of PPAR $\gamma$ and aP2 genes in adipose tissue: Possible features of the antiobesity effects of a $\beta 3$-adrenergic agonist. Biochemistry Pharmacy, 61, 1471-1478.

Martínez, J. A., Moreno, B., \& Martínez-Gonzales, M. A. (2004). Prevalence of obesity in Spain. Obesity Reviews, 5(3), 171-172.

Medina, G., Sewter, C., \& Vidal-Puig, A. J. (2000). Revisión: PPAR $\gamma$ y tiazolidinedionas, algo más que un tratamiento contra la diabetes. Medicina Clínica, 115, 392-397.

Meirhaeghe, A., Helbecque, N., Cottel, D., \& Amouyel, P. (1999). B2adrenoceptor gene polymorphism, body weight, and physical activity. Lancet, 353(3), 896.

Meirhaeghe, A., Luan, J., Selberg-Franks, P., Hennings, S., Mitchell, J., \& Halsall, D. (2001). The effect of the Gly16Arg polymorphism of the beta(2)-adrenergic receptor gene on plasma free fatty acid levels modulated by physical activity. Journal of Clinical Endocrinology and Metabolism, 86(12), 5881-5887.

Miles, L. E. M., Lipschitz, D. A., Bieber, C. P., \& Cook, J. D. (1974). Measurement of serum ferritin by a 2-site immunoradiometric assay. Analytical Biochemistry, 61, 209-224.

Monteiro, C. A., \& Halpern, A. (2000). Epidemiología de la obesidad en Brasil. Nutrición y Obesidad, 3(2), 98-105.

Monteiro, J. B. R., \& Mourão, D. M. (2002). Ingestão alimentar versus propriedades sensoriais e fisicoquímicas dos alimentos. Abeso, ano, III (9), 6-8.

Mori, Y., Kim-Motoyama, H., Katakura, T., Yasuda, K., Kadowaki, H., Bearmer, B. A., et al. (1998). Effect of the Pro12Ala variant of the human peroxisome proliferator-activated receptor $\gamma 2$ gene on adiposity, fat distribution, and insulin sensitivity in Japanese men. Biochemistry Biophysical Research Community, 251, 195-198.

Mourão, D. M., Monteiro, J. B. R., Hermsdorff, H. M., \& Leite, M. C. T. (2004). Effect of sucrose and sweetener on appetite sensation and energy expenditure in normal weight and overweight subjects. Revista Brasileira de Nutrição Clínica, 19(2), 47-53.

Mullis, K. B., \& Falooma, F. A. (1987). Specific synthesis of DNA in vitro via a polymerase-catalyzed chain reaction. Methods of Enzymology, $155,335-350$.

NCEP. (2001). Executive summary of the third report of the national cholesterol education program (NCEP) Expert Panel on detection, evaluation and treatment of high blood cholesterol in adults (Adult treatment panel III). JAMA, 285, 2486-2497.

Palou, A., Bonet, M. L., \& Rodríguez, A. M. (2001). El sistema de control del peso corporal y la obesidad a la luz de la tecnología de los transgénicos. Nutrición y Obesidad, 4(5), 221-251.

Perusse, L., Chagnon, Y. C., Weisnagel, S. J., Rankinen, T., Snyder, E., Sands, J., et al. (2001). The human obesity gene map: The 2000 update. Obesity Research, 9(2), 135-169.

Pesquisa Nacional de Orçamentos Familiares (POF). (2004). Análise da biodisponibilidade domiciliar de alimentos e do estado nutricional no Brasil. Instituto Brasileiro de Geografia e Estatística (IBGE). 75pp.

Piers, L. S., Walker, K. Z., Stoney, R. M., Soares, M. J., \& O'Dea, K. (2002). The influence of the type of dietary fat on postprandial fat oxidation rates: Monounsaturated (olive oil) vs saturated fat (cream). International Journal of Obesity, 26, 814-821.

Ravussin, E., \& Bogardus, C. (2000). Energy balance and weight regulation: Genetics versus environment. British Journal of Nutrition, $83, \mathrm{~S} 17-\mathrm{S} 20$.

Spiegelman, B., Castillo, G., Hauser, S., \& Puigservar, P. (1999). Regulation of energy balance by PPAR $\gamma$ and its coactivators. In Guy-Grand, B., \& Ailhaud, G. (Eds.). Progress in obesity research. 8 (chapter 5), 39-46. 8th International Congress on Obesity.

Valet, P., Grujic, D., Wade, J., Ito, M., Zingaretti, M. C., Soloveva, V., et al. (2000). Expression of human alpha 2-adrenergic receptors in adipose tissue of beta 3 -adrenergic receptors-deficient mice promotes diet-induced obesity. Journal of Biological Chemistry, 275(44), 34797-34802.

Valtueña, S., Blanch, S., Barenys, M., Solá, R., \& Salas-Salvadó, J. (1995). Changes in body composition and resting energy expenditure after rapid weight loss: Is there an energy-metabolism adaptation in obese patients? International Journal of Obesity, 19(2), 119-125.

Valve, R., Sivenius, K., Miettinen, R., Pihlajamäki, J., Rissanen, A., Deeb, S. S., et al. (1999). Two polymorphisms in the peroxisome proliferatoractivated receptor- $\gamma$ gene are associated with severe overweight. Journal of Clinical Endocrinology and Metabolism, 84(10), 3708-3712.

van Rossum, C. T., Hoebee, B., Seidell, J. C., Bouchard, C., van Baak, M. A., \& de Groot, C. P. (2002). Genetic factors as predictors of weight gain in young adult Dutch men and women. International Journal of Obesity, 26(4), 517-528.

Vidal-Puig, A., Jiménez-Liñan, M., Lowell, B. B., Hamann, A., Hu, E., Spielgeman, B., et al. (1996). Regulation of PPARg gene expression by nutrition and obesity in rodents. Journal of Clinical Investigation, 97(11), 2553-2561.

Weinsier, R. L., Nelson, K. M., Hensrud, D. D., Darnell, B. E., Hunter, G. R., \& Schutz, Y. (1995). Metabolic predictors of obesity. Contribution of resting energy expenditure, thermic effect of food, and fuel utilization to four-year weight gain of post-obese and neverobese women. Journal of Clinical Investigation, 95(3), 980-985.

WHO. (1985). Energy and protein requirements. Report of a joint FAO/ WHO/ONU Expert Consultation. Technical report series 724. Geneva, World Health Organization.

WHO, (1998). Obesity: Preventing and managing the global epidemic. Report of a WHO Consultation on obesity.

Wolff, G. L. (1997). Overview in obesity: Common symptom of diverse gene-based metabolic deregulations. Journal Nutrition, 127(9 Suppl.), 1871-1873. 